\title{
Sicilya Normanlarının Son Feri: 1185 Selânik Saldırısı
}

\section{The Final Luster of Normans of Sicily: the Attack on Thessaloniki in 1185}

\author{
Zeki Can Hırçın' ${ }^{0}$
}

'Sorumlu yazar/Corresponding author: Zeki Can Hırçın (Doktora Öğrencisi), Szeged Üniversitesi, Doktora Tarih Okulu, Szeged, Macaristan.

E-posta: zchircin@hist.u-szeged.hu ORCID: 0000-0002-7071-3028

Başvuru/Submitted: 23.01.2021 Revizyon Talebi/Revision Requested: 03.02.2021

Son Revizyon/Last Revision Received: 09.02.2021

Kabul/Accepted: 27.04 .2021

Atif/Citation: Hircin, Zeki Can, “Sicilya Normanlarının Son Feri: 1185 Selânik Saldıısı", Güneydoğu Avrupa Araştırmaları Dergisi, 37 (2021), s. 59-78

https://doi.org/10.26650/gaad.867098 öz

Sicilya Krallığı'nın üçüncü kralı olan, lyi lâkaplı II. William'ın dış siyaseti her zaman maceraperest olmuştu. 1170'lerde üç defa Mısır'a, 1181'de Balear adalarına düzenlediği çıkarmalar krallık için pahalı ve sonuçsuz girişimler olarak kalmış olmasına rağmen William bu seferlerin hepsinden daha büyüğüne kalkışacak ve bu girişim Hauteville sülâlesinin kısa sürede tarihten çekilmesine yol açacaktı. Bizans'la savaşarak tarih sahnesine çıkan hânedan, son enerjisini yine onunla savaşarak tüketti. İtalya Normanları ve Bizans İmparatorluğu arasında kronikleşmiş olan düşmanlığın devamı sayılabilecek çatışma, Kral William'ın kişisel düşmanlığıyla birleşerek imparatorluğun ikinci büyük şehri Selânik üzerinde yoğunlaştı. Bizans için çok hassas bir döneme tesadüf eden olaylar zinciri, Komnenos hânedanının imparatorluk tacını kaybetmesine sebep olacak, IV. Haçı Seferi'ne kadar giden Latin saldırganlığının ilk ciddi işareti olacaktı. Çalışmada 1185 yılında Bizans'ın ikinci başkenti olarak addedilen Selânik kentine Sicilya Normanları tarafından düzenlenen saldırı değerlendirilecektir.

Anahtar Kelimeler: Selânik, Normanlar, Bizans, II. William, I. Andronikos

\section{ABSTRACT}

The foreign policy of William II, the third king of Sicily named the Good, was always venturesome. Even though the expeditions in three occasions to Egypt in 1170s and in one occasion to the Balearic Islands in 1181 resulted in nothing for the Kingdom at large expense, William was going to embark on a much bigger enterprise and this last one was going to pave the way for the Hauteville family to disappear from the history. The Family which gained visibility thanks to their fight with the Byzantines, was going to wear down due to the same reason. The habitual conflict between Italo-Normans and the Byzantine Empire fuelled by the King's personal grudge against the Empire focused on Thessaloniki, the second largest city of Byzantium. Being one of the first signs of the Latin aggression that reaches up to the Fourth Crusade, this chain of events which coincides with a critical period 
of the Byzantines was going to result in dethroning of the Komnenos dynasty. The article studies the campaign of Sicilian Normans on the city of Thessaloniki, regarded as the second capital of Byzantium.

Keywords: Thessaloniki, Normans, Byzantium, William II, Andronikos I.

\section{EXTENDED ABSTRACT}

In this article we focus on the causes, the scene, and the impact of the siege of Thessaloniki in 1185 by the Italo-Norman forces against the Byzantine Empire. 'Adventurous' king William II, the third king of Sicily called the Good, inherited an old animosity from his ancestors and considered that the time was ripe for the Kingdom of Sicily to launch forth an invasion of the Byzantine Empire, given its condition during the period. The Byzantines were ruled with terror by the tyrannical Andronikos I, so much so that the prominent class in the Empire dispersed towards the periphery of the Empire in fear of their lives and in some cases even supported the Normans. If one were to select three different periods of internal disorder in the entire history of the Byzantine Empire, Andronicus' term would definitely be included. In other words, Eastern Empire writhed in pain in the hands of a descendent of its savior dynasty. Nevertheless, it was still the Roman Empire.

Looking at the aggressors, settled in Sicily, the aptly-titled Kingdom of Sicily was a powerhouse in the center of Mediterranean. A Norman power had somehow flourished in South Italy against puissance of the popes and the Holy Roman Empire, along with the Byzantine Empire. It became a kingdom in 1130 and later the pivot in the central Mediterranean by dominating Ifriqiya around the mid-twelfth century. Although its domination was short-dated in Ifriqiya, the Norman Kingdom continued to control the trade routes between European Mediterranean ports and Eastern coastal areas as a wealthy and powerful kingdom. It retained most of its power until the coronation of William II in 1166. From 1171 onwards, after his infancy, William II adapted an adventurous and ambitious foreign policy. Oversea expeditions of William II on three occasions to Egypt in 1170s had the aim to defend the Crusader States, but these ventures did not have any tangible outcome; and on one occasion to the Balearic Islands in 1181 resulted in a similar conclusion. These oversea campaigns were carried at a substantial financial expense by the Kingdom. Nevertheless, the Kingdom was wealthy, and William was eager to undertake a much bigger enterprise. The habitual conflict between the Italo-Normans and the Byzantine Empire, supported by the King's personal grudge against the Empire was now focused on Thessaloniki, the second largest city of the Eastern Empire. The siege was successful, and it was concluded in a short time of nine days, but the aftermath was going to be inauspicious for the aggressors. The Hauteville Family that first gained visibility thanks to their fight with the Byzantines, was going to exhaust all its energy and resources due to the same reason. 
Along with its brand-new ruling dynasty, the Angelos, the refreshed Empire could face their fearful enemy. Withdrawing in front of the eager Imperial forces in the western Thrace, the Normans would have felt that this retreat was just a beginning. Indeed, the Norman Kingdom of Sicily was going to disappear from history in less than 10 years after that conflict.

On the other hand, the chain of events triggered by the Norman attack, which coincided with a critical period in the Byzantine history, was going to result in dethroning of the powerful Komnenos dynasty on behalf of the Angelos, mostly deemed weak by the modern historians. However, the siege against the Eastern Empire is the one of most prominent signs of the Latin aggression that was going to reach up to the Fourth Crusade. 


\section{Giriş}

Selânik saldırısı Akdeniz Normanları tarihinin en önemli olaylarından biri olsa da konuyu Sicilya tarafından ele alan herhangi bir kronikçi bulunmamaktadır. Sadece Bizanslı iki kronikçiden öğrenebildiğimiz gelişmeler hâliyle eksik kalmaktadır. Bununla birlikte mezkûr kronikçilerin eserleri sayesinde Selânik'e yapılan Norman çıkarması hakkında oldukça ayrıntıı bilgilere ulaşmak mümkündür.'

Normanlar, XI. yüzyılın ilk çeyreğinde kalabalıklaşmaya başladıkları Güney İtalya'da, bölgedeki başat güç olan Bizans İmparatorluğu'yla çatışmaya girmişlerdi. Aşağı yukarı 50 yıl içinde İmparatorluk otoritesini Güney İtalya'daki birkaç müstahkem mevkiye sıkıştırdılar. Bizans için imparatorluk tarihinin en kötü yıllarından biri olarak sayılabilecek 1071'de, Normanlar üç yıllık kuşatmanın sonunda Bari'yi ele geçirerek imparatorluğu Mezzogiorno'dan² kesin olarak çıkardılar. ${ }^{3}$ Normanları korkulan bir siyasi güç hâline getiren Robert Guiscard (1059-1085), 1081'de doğrudan Bizans Imparatorluğu tahtııı hedef aldı. Bu sırada Alman İmparatoru IV. Heinrich'in (1056-1105) Roma'ya yürümesi üzerine Papa VII. Gregorius (10731085) Guiscard'dan yardım istedi. Alman ordusunun tehdidi altındaki Roma'ya yardım etmek isteyen Guiscard, büyük umutlarla giriştiği seferini terk etmek zorunda kaldı. ${ }^{4}$ Güney İtalya Normanları'nın Bizans'a karşı düşmanca tutumu, Guiscard'ın oğlu ve ilk Antakya Prinkepsi ${ }^{5}$

1 Konunun Bizanslı iki kaynağı bulunmaktadır. Bunlardan Eustathios'un eseri, Konstantinopolis'teki gelişmelerden de haber vermekle birlikte doğrudan doğruya Selânik'in düşüşüyle ilgili birinci elden bir kaynaktır. Khoniates ise genel Bizans kronikçisi olarak özellikle Selânik'in düşüşünden sonraki gelişmeler hakkında bilgi vermektedir. Bkz.: Eustathios of Thessaloniki, The Capture of Thessaloniki, İngilizce çev. John R. Melville Jones, Canberra 1988; Niketas Khoniates, Niketas Khoniates'in Historia'sı (1 180-1195): Komnenos Hânedanı'nın Sonu ve II. Isaakios Angelos Devri, çev. Işın Demirkent, İstanbul, 2006. Eustathios ve Khoniates'in içinde bulunduğu koşullar, hayat öyküleri ve eserleriyle ilgili bkz.: Warren Treadgold, The Middle Byzantine Historians, Basingstoke, 2013, s. 416-456; Konunun 135 yıllık bir periyoda yayılan literatürü için bkz.: Isidoro la Lumia, Storie Siciliane, Palermo 1881, I, 489-539; Ferdinand Chalandon, Histoire de la Domination Normande en Italie et en Sicile, Paris, 1907. II, 400-415; Oreste Tafrali, Thessalonique des origines au XIVe siècle, Paris, 1919, s. 182-191; Hélène Ahrweiler, Byzance et la Mer, la marine de guerre: la Politique et les Institutions Maritimes de Byzance aux VIle-XVe siecles, Paris, 1966, s. 283-288; Charles M. Brand, Byzantium Confronts the West 1180-1204, Cambridge, Massachusetts: Harvard University Press, 1968, s. 160-175; John Julius Norwich, The Kingdom in the Sun 1130-1194, New York, 1970, s. 331-344; Pierre Aubé, Les empires normands d'Orient: XIe-XIlle siècle, Paris, 1983, s. 231-236; Randall Rogers, Latin Siege Warfare in the Twelfth Century, Oxford, 1992, s. 121-123; Paul Stephenson, Byzantium's Balkan Frontier a Political Study of the Northern Balkans, 900-1204, Cambridge, 2000, s. 284-288; Charles D. Stanton, Norman Naval Operations in the Mediterranean, Woodbridge, 2016, s. 150-156.

2 İtalyancada tam karşıı̆ı gün ortası, öğlen anlamına gelmektedir. Öğlenleri gün ışığını yoğun olarak alan, kabaca Lazio bölgesinin güneyinde kalan eyaletlerle birlikte Sicilya ve Sardinya Adası'nı da kapsayan bölgeye verilen isimdir. Kelime ilk olarak XVIII. yüzyılda kullanılmaya başlandığından dolayı ele alınan dönem için anakronik olsa da kabaca Napoli Krallığı'nın sınırlarına karşılık gelen Güney İtalya'yı belirtmek için kullanılmıştır. Bkz.: "Mezzogiorno", Britannica içinde, (23 Aralık 2021). Erişim adresi: https://www.britannica.com/place/Mezzogiorno.

3 Chalandon, Histoire de la Domination Normande, I, 186-190; Georg Ostrogorsky, Bizans Devleti Tarihi, Ankara: TTK, 2015, s. 320; Rogers, Latin Siege Warfare, s. 96-97; G. A. Loud, The Age of Guiscard: Southern Italy and the Norman Conquest, New York, 2013, s. 134-136; Stanton, Norman Naval Operations, s. 43-44.

4 Chalandon, Histoire de la Domination Normande, I, 265-282; Loud, The Age of Guiscard, s. 214-219; Georgios Theotokis, The Norman Campaigns in the Balkans 1081-1108, Woodbridge, 2014, s. 143-184.

5 Antakya Haçlı Prinkepsliği'nin kuruluş ve yerleşme süreci hakkında bkz.: Ebru Altan, Antakya Haçlı Prinkepsliği Tarihi, Kuruluş Devri (1098-1112), Ankara: TTK, 2018. 
Bohemond (1098-1111) zamanında da sürecekti. Bohemond'un, 1107'de, Papa II. Paskal'ın (1099-1118) yardımıyla haçlı motifleriyle bezenmiş, doğrudan İmparatorluk tahtını hedef alan saldırısı da başarısız oldu. ${ }^{6}$

İtalya Normanlarını tek çatı altında birleştirerek Palermo merkezli Sicilya Norman Krallığı'nı kuran II. Roger, topraklarına Kutsal Roma-Germen İmparatorluğu ve Bizans İmparatorluğu ortaklığında büyük bir saldırı beklerken Urfa İmâdüddin Zengî tarafından fethedildi. Bu fetih Avrupa'da büyük bir infial yaratarak yeni bir haçlı seferi ${ }^{7}$ çağrısı yapılmasına sebebiyet verecekti. Avrupa'da birçok hükümdarın yeni bir seferin hazırlıklarını yaptığı sırada Sicilya Kralı, Bizans'ın ve Almanların ortak saldıı planının rafa kalktığını görerek derin bir nefes aldı. Ancak Roger bununla yetinmeyecekti. İmparatorluk topraklarından geçen Fransız ve Alman haçlı ordularıyla uğraşmak zorunda kalan Bizans'ın müşkül durumundan istifade eden Norman güçleri, 1147 sonu 1148 yılı başlarında Yunanistan'ın Mora kıyılarını yakıp yıktı ve toplanan büyük ganimete bölgedeki Bizanslı ipek dokumacılarını da ekleyerek Sicilya'ya döndü. ${ }^{8}$ Ancak bu yağma amaçlı bir saldırıydı. Bu saldırıya karşı 1156 yılında Puglia'ya (Apulia) asker yollayan İmparator I. Manuel'e (1143-1180), Kötü lâkaplı I. William'ın (1154-1166) misillemesi hemen ertesi yıl geldi. Büyük bir donanmayla sefere çıkan Normanlar, Eğriboz Boğazı'nda rastladıkları kalabalık bir Bizans donanmasını yok ederek Yunanistan kıyıları boyunca kuzeye doğru ciddi hasarlar vererek ilerlediler ve doğuya dönerek Çanakkale Boğazı'nı geçtiler. Marmara Denizi'nden Konstantinopolis surları önüne kadar gelen Norman donanmasının askerleri, kralları William'ın adını haykırıp Bizans Sarayı'na gümüş saplı oklar yağdırdıktan sonra Sicilya'ya geri döndüler. ${ }^{9}$ Bu saldırı her ne kadar cesurca görünse de Guiscard ve Bohemond'un ihtiraslı girişimlerinden farklı olarak İmparatorluğa karşı sadece gözdağı niteliğindeydi.

\section{Saldırının Nedeni}

I. William'ın edilgen dış siyaseti oğlu II. William (1166-1189) tarafından devam ettirilmedi. II. William'ın krallığında Normanlar tekrardan zor hedefler için atılgan bir politika izleyecekti. Bununla birlikte Normanların İtalya'ya inişlerinden beri Hauteville ailesinin en büyük ihtirası Bizans İmparatorluk tacıydı. Normanlar bu cüretkâr hedefe II. William döneminde hiç olmadığı kadar yaklaşacak, ancak umulanın aksine bu girişim hânedanın sonunu getirecek olaylar zincirinin önemli bir halkasını teşkil edecekti.

II. William'ın Doğu İmparatorluğu tahtını hedef alan saldırısının nedenlerine baktığımızda, ilk olarak Normanlar için neredeyse bir kuruluş ülküsü olarak varsayılabilecek Bizans düşmanlığının devam ettiği fark edilir. Ayrıca kralın reşit olmasından itibaren izlediği dış siyaset

6 Theotokis, The Norman Campaigns in the Balkans, s. 200-213.

7 Kurulan ilk Haçlı devleti olan Urfa Kontluğu'nun başşehri Urfa'nın Müslümanlar tarafından ele geçirilmesinin Avrupa'da yarattığı reaksiyon sonucunda düzenlenen II. Haçıı Seferi hakkında bkz.: Ebru Altan, Ikinci Haçlı Seferi (1147-1148), Ankara: TTK, 2003.

8 Chalandon, Histoire de la Domination Normande, II, 135-137; Ostrogorsky, Bizans Devleti Tarihi, s. 354; Stanton, Norman Naval Operations, s. 93-97.

9 Chalandon, Histoire de la Domination Normande, II, 247-248; Stanton, Norman Naval Operations, s. 135. 
her zaman büyük hedefler peşindeydi. Bunlara ek olarak, William, uzun müzakereler sonucunda İmparator I. Manuel'in kızı Maria ile nişanlanmıştı. Ancak Taranto Limanı'nda beklediği nişanlısının gelmemesinin verdiği aşağılanma, ondaki İmparatorluk düşmanlığını ata yadigârı siyasetten kişisel bir hırsa da taşımış görünmektedir. ${ }^{10}$

Bizans'ta ise İmparator Manuel'in ölümünden sonra oğlu II. Aleksios (1180-1183) annesi Maria'nın niyâbetiyle tahta çıktı. ${ }^{11}$ Maria'nın ${ }^{12}$ Latin olması sebebiyle halk arasında hâlihazırda az olan itibarı, mütevaffâ imparatorun sevilmeyen yeğeni protosebastos ${ }^{13}$ Aleksios Komnenos'la kurduğu yakın ilişki sebebiyle Komnenos sülâlesi içinde de azaldı. ${ }^{14}$ Mezkûr hânedan içindeki Latin karşıtı partinin başını çeken Andronikos Komnenos'un yıllardır beklediği fırsat ayağına kadar gelmişti. Konstantinopolis surları içindeki halkın dışarıda bekleyen Andronikos kuvvetlerine yardımı ile Latinlere karşı büyük bir katliamın izlediği darbe eliyle Maria ve protosebastos tahttan indirildi. ${ }^{15}$ Latin katliamının yarattığı akis, Batı'daki Bizans düşmanlığına ciddi bir ivme kazandıracak ve Norman saldırısının en önemli gerekçelerinden biri sayılacaktı. Çocuk yaştaki İmparator Aleksios'un hâmîsi olarak devleti yönetmeye başlayan I. Andronikos (11831185), ortak imparator ilân edildikten hemen sonra Aleksios'u öldürterek tek imparator oldu. Bundan sonra tedhiş rejimini özellikle Bizans asalet sınıfı üzerinde dayanılmayacak boyutta uygulamaya koyacak ve onun döneminde devlet adeta kaynayan bir kazana dönüşecekti. ${ }^{16}$

Selânik Kuşatmasının doğrudan görgü tanığı ve Selânik başpiskoposu Eustathios'un yorumuna göre; Sicilya Kralı II. William, İmparator I. Manuel'in yukarıda bahsedilen Puglia saldırısından dolayı ona garez beslemekteydi. Bununla birlikte, İmparator Andronikos'un tedhiş

10 Salernolu Romuald, Romualdi Salernitani Chronicon [A. m. 130 - A. C. 1178], ed. C. Garufi, Rerum Italicarum Scriptores, nuova editione, vol. VII, Città di Castello, 1935, s. 261. "(1172) Eo tempore cum Emmanuel imperator Constantinopolitanus frequentibus nuntiis delegatis filiam suam Zura Mariam W[ilhelmo] regi Sicilie in uxorem tradere promisisset, tandem ex conuentione utriusque partis factum est, quod imperator, presentibus legatis eiusdem regis, in anima sua iurare fecit, et iuramentum suum' magnatimi suorum iureiurando firmari, quod in termino et loco ab utraque parte prefixo filiam suam regi prò uxore transmitteret. Et simile iuramentum ex parte regis et suorum familiarium de filia imperatoris recipienda prestitum est et iuratum. Quo facto, rex W[ilhelmus], utpote uir legalis et Deum metuens, iuramentum suum obseruare desiderans, simul cum Henrico fratre suo Capuanorum principe Tarentum uenit, et ibi nuntios imperatoris cum eius filia in prefixo loco et termino aliquandiu expectauit."

11 Eustathios, The Capture of Thessaloniki, s. 18-19; Khoniates, Niketas Khoniates'in Historia'sı, s. 1, 59.

12 Imparator Manuel'in ikinci eşi ve Antakya Prinkeps'i Raymon de Poitiers'nin kızı Maria-Xena, Konstantinopolis halkı tarafından hiçbir zaman sevilmemişti. Bkz.: Ioannes Kinnamos, loannes Kinnamos Historia'sı (11181176), çev. Işın Demirkent, Ankara: TTK, 2001, s. 153 vd., 185; Niketas Khoniates, Historia (loannes ve Manuel Komnenos Devirleri), çev. Fikret Işıltan, Ankara, 1995, s. 79, 117; Khoniates, Niketas Khoniates'in Historia'sı, s. 10, 15-16.

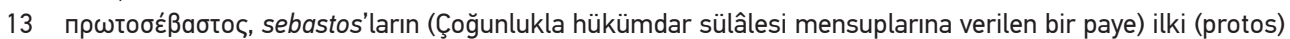
anlamına gelmektedir. I. Alexios (1081-1118) zamanında ortaya çıkan unvanlardan biri olduğu varsayılır. XII. yüzyılda sadece iktidarda olan sülâlenin mensupları bu unvanı taşıyabiliyorlardı. İmparatorluğun son yüzyıllarında değeri giderek azalmıştır. Bkz.: L. P. Raybaud (Gouvernement), "Protosebastos", The Oxford Dictionary of Byzantium, III, 1747.

14 Khoniates, Niketas Khoniates'in Historia'sı, s. 3.

15 Eustathios, The Capture of Thessaloniki, s. 32-35; Khoniates, Niketas Khoniates'in Historia'sı, s. 31-37.

16 Khoniates, Niketas Khoniates'in Historia'sı, s. 39-82. 
rejimi mağdurları, William'a İmparator tarafından Kırım'a sürülmüş Aleksios Komnenos'un ${ }^{17}$ liderliğinde bir elçilik heyeti yolladı. Khoniates'e göre, yanında Philippopolis Vâlisi Maleinos da bulunan Aleksios, İmparatorluk topraklarında çok sevildiğinden ve desteklendiğinden bahsederek Sicilya Kralı'na yardım edeceğini vurguladı. Ayrıca Aleksios, Andronikos'un hışmına uğrayarak İmparatorluk'tan kaçıp Sicilya'ya gelen Latin paralı askerlerinden de destek gördü. Eustathios'a göre ise; Aleksios'un gerçek niyeti Bizans imparatorluk tacıydı. Sicilya Kralı da krallığını başka birine devrederek Konstantinopolis'e taşınma hayalleri kuruyordu. ${ }^{18}$

O günlerde Sicilya'ya bir başka Aleksios daha gelmişti. Bahsedilen kişi, İmparator II. Aleksios olduğunu iddia ediyordu. ${ }^{19}$ Ayrıca yanında onun iddialarına destek olan bir keşiş de bulunmaktaydı. Kendini Sikountenos Philadelphenos ismiyle tanıtan adam, Eustathios'a göre ata binişindeki ustalığı ve belinden sarkan kılıcıyla daha çok "sakallı" bir Latin savaşçısını andırıyordu. Başpiskoposa göre hem keşiş hem de yanındaki Aleksios, Bagentia'dan²0 gelen alelâde kişilerdi. Yaşı ve görüntüsüyle gerçek Aleksios'la benzerlikler taşıyan çocuğun yanındaki keşiş ona bir imparatora nasıl davranılması gerekiyorsa öyle davranıyordu ancak Eustathios'a göre "sahtekâr" keşişin yanındaki çocuk da çiftçi bir köylüydü. Kralın sarayına getirilen çocuk ve koruyucusu kralın emriyle sağlam bir soruşturmadan geçirilmiş olmasına karşın, Adriyatik kıyısındaki Bizans topraklarındaki Andronikos'tan gayri memnun halkın da şahitliğinde gerçek Aleksios ilan edildi. Ayrıca İbn Cübeyr'e (ö. 1217) göre o sırada Palermo'da bulunan Cenevizli tâcirler de Aleksios'un gerçekliği lehinde şahitlik etmişlerdi. Bununla birlikte William Aleksios'un gerçekliğinden şüphe duymasına rağmen, Andronikos'un adamları tarafından öldürülmesinden çekinerek onu gözetim altında tutmaktaydı. ${ }^{21} \mathrm{Kral}$, durumun farkında olmasına karşın Bizans tacı için duyduğu ihtirasın gücüyle bu tiyatroya devam edilmesinden yana tavır aldı. ${ }^{22}$ Zira büyük büyük amcası Robert Guiscard da Bizans saldırısına başlamadan önce buna benzer bir gerekçeyle harekete geçmişti. ${ }^{23}$

Kral II. William, Bizans'a karşı Sicilya Krallığının bütün gücünü sevk etmeden önce, Normanlar için her zaman en ciddi tehdit olan Alman imparatorlarının İtalya'ya inmesinden korkarak, II. Roger'nin kızı, halası Constance'ın Alman İmparatorluğu vârisi Heinrich'le evlenmesine razı oldu. Halasını Almanya'ya göndermeden önce William, 1185 yılında, krallığın

17 Burada bahsedilen Aleksios Komnenos, I. Manuel'in sakisi (kupa taşıyıcısı) ve yeğeninin oğluydu. Aleksios aynı zamanda yukarıda da bahsedilmiş olan, Andronikos yanlıları tarafından yerinden edilen protosebastos Aleksios Komnenos'un yeğeniydi. Bkz: Khoniates, Niketas Khoniates'in Historia'sı, s. 82.

18 Eustathios, The Capture of Thessaloniki, s. 58-61; Khoniates, Niketas Khoniates'in Historia'sl, s. 82-83.

19 Eustathios'a (The Capture of Thessaloniki, s. 52-53) göre İmparator Aleksios'un Sicilya'da olduğu söylentisi kulağına geldiğinde onun katili Andronikos Komnenos: "Konstantinopolis denizinin dibini boyladıktan sonra oraya kadar nefes almaksızın yüzebildiğine göre o gerçekten iyi bir yüzücü olmalı” diyerek alay etmişti.

20 Brand, doğrudan İlirya'daki Vonizza Kasabası'nın ismini verirken; Stanton kasaba ismi vermeksizin Korfu'nun karşısında günümüzdeki adıyla Sesprotya, o zamanki adıyla Vagenetia bölgesini işaret etmektedir. Bkz.: Brand, Byzantium Confronts the West, s. 161; Stanton, Norman Naval Operations, s. 151.

21 İbn Cübeyr, Riḥletü'l-Kinânî, çev. İsmail Güler, Endülüsten Kutsal Topraklara, İstanbul, 2008, s. 253-254.

22 Eustathios, The Capture of Thessaloniki, s. 61-63.

23 Chalandon, Histoire de la Domination Normande, II, 265; Loud, The Age of Guiscard, s. 214. 
birçok soylusunun da hazır bulunduğu Puglia bölgesinin Troia şehrindeki bir toplantıda Constance'ı meşru vârisi olarak gördüğü üzerine yemin etti. ${ }^{24} 1185$ yılında 31 yaşında olan William'ın henüz çocuğu bulunmuyordu ve ettiği yeminle birlikte halası Constance tahtın meşrû vârisi konumundaydı. ${ }^{25}$ Bununla ilgili Stanton'un yorumu etkileyicidir: William krallığını, cinsel iktidarının gücüne güvenerek bahis konusu yaptı. Bu kötü bir kumardı. ${ }^{26}$ Gerçekten de Germen imparatorlarının bir asırdan fazladır silâhla gerçekleştirmeye çalıştıkları Güney İtalya hâkimiyeti I. Friedrich Barbarossa'nın (1155-1190) ısrarla istediği evlilik planıyla gerçekleşecek, II. William'ın Alman cephesinden çekinerek aldığı bu önlemin neticeleri Hauteville'ler için ölümcül olacaktı.

Palermo ve Messina başpiskoposları İmparatorluğa karşı sefere muhalefet ettiler. ${ }^{27} \mathrm{An}-$ cak Bizans'a saldırı zamanının geldiğini düşünen William onları dinlemeyecekti. Sicilya Kralı, yukarıda Manuel'in sakisi olarak bahsedilen ${ }^{28}$ Aleksios Komnenos'un ona Konstantinopolis'in anahtarını kolayca vereceğini iddia etmesi üzerine harekete geçti. 1185 yılının ilk aylarında Sicilya Kralı'nın çağrısıyla birçok ülkeden savaşçı Sicilya için yola çıktı. ${ }^{29}$ Sûr'lu William'ın zeylinde, Sûr başpiskoposu Josias'ın, Hittîn'deki Haçlı hezimetini Papa'ya bildirmek için Roma'ya giderken karaya çıktığı Sicilya Krallığı topraklarında William'la yaptığı görüşmeden aktarılana göre; kral, başpiskoposa bu felâketin kısmen de olsa kendi sorumluluğu olduğunu belirtmişti. Zira yazar, Haçlıların uğradığı hezimetten iki yıl önce, Sicilya Kralının Bizans'a karşı yürüteceği saldırıda, ne kadar adam bulabilirse toplamaya çalıştığını; büyük bir donanma hazırladığını; çevredeki illerle yetinmeyip Outremer' $\mathrm{e}^{30}$ kadar adamlar yollayarak tecrübeli askerlere ve şövalyelere statüleri karşılığında ödeme vaat edip ülkesine çektiğini; hatta iki yıl boyunca ${ }^{31}$ Outremer yolunu kapatarak hacıların geçişini engellediğinden bahsediyor. Bütün bunların Latin Doğu'yu

24 Annales Cassinenses, a. 1000-1212, ed. G. Pertz, Monumenta Germaniae Historica, Scriptores, XIX, Hannover, 1866, anno 1185, 1190, s. 313-314.

25 Chalandon, Histoire de la Domination Normande, II, 386.

26 Stanton, Norman Naval Operations, s. 151.

27 Eustathios, The Capture of Thessaloniki, s. 62-63. Eustathios (aynı yerde) Palermo ve Messina başpiskoposlarının muhalefetinin yerinde olduğunu belirtip, bir zamanlar Konstantinopolis İmparatoru'nun tâbisi olan Sicilya Kontları'nın dünya imparatoru sıfatııı almasının mümkün olamayacağından bahsederek William'ı aşağılamaktadır.

28 Bkz.: 17. dipnot.

29 Eustathios, The Capture of Thessaloniki, s. 62-63; Khoniates, Niketas Khoniates'in Historia'sl, s. 110-111.

30 Modern Fransızcada da kullanılan Outremer (Outre-mer şeklinde) terimi deniz aşırı (topraklar) anlamına gelmektedir. Avrupa'nın bakış açısına göre Akdeniz'in uzak karşı tarafı anlamını taşımaktadır. Hem Ortaçağ kaynaklarında hem günümüz akademik terminolojisinde kullanılan terim, dört Haçlı Devleti'nin (daha sonrasında hangileri kalmışsa onların) hâkimiyetindeki toprakların bütününü ifade eder. Bkz.: Alan V. Murray, "Outremer”, The Crusades: An Encyclopedia (Santa Barbara, 2006), III, 911-912.

31 Devamında da göreceğimiz gibi Sicilya limanlarının iki yıl boyunca gemi giriş çıkışına kapatılması iddiası abartıı bir yorumdur. 
zayıflatarak Hittîn'deki hezimete neden olduğunu, savaş sonrasında da birçok Haçlı şehrinin ve kalesinin de savunmasız kalarak Selahaddin'in eline kolayca düştüğünü kaydetmektedir. ${ }^{32}$

\section{Selânik Kuşatması}

William, 1185 yılının Ocak ayından itibaren Sicilya limanlarında bulunan bütün gemilere çıkış yasağı koydu. ${ }^{33}$ Eustathios'a göre; aralarında at taşıyan gemiler de dahil çeşitli tiplerde 200 'den fazla gemi doğrudan krallık topraklarından temin edilirken, Siphantos ${ }^{34}$ adında birinin komutasındaki bir korsan grubu da Sicilya filosuna eşlik edecekti. ${ }^{35}$ İbn Cübeyr'in duyduklarına göre ise içlerinde dromon ${ }^{36}$ ve kadırgaların da olduğu 300'den fazla gemi hazırlanmıştı, hatta bunlara erzak taşıyan 100'den fazla gemi de eşlik edecekti. Endülüslü seyyah, hazırlıkların düzgün bir şekilde yapılıp yapılmadığını kontrol etmek için William'ın bizzat Messina'da bulunduğunu zikretmektedir. ${ }^{37}$ Eustathios'un Normanlardan daha sonrasında öğrendiğine göre, kara ordusu, 5.000 atlı süvari (ağır süvari); bir kısmı atlı okçu; bir kısmı hafif piyade ve son olarak da Normanların rizico diye ifade ettiği, herhangi bir harcırah almayan, yağmaya bel bağlamış bir birliğin de bulunduğu toplamda 80.000 kişiden oluşmaktaydı. Başpiskoposa göre bütün bu hazırlıklar Sicilya Krallığı'nın hazinesini boşaltmıştı. ${ }^{38}$

Gemilere Sicilya'dan çıkış yasağı getirilmişti. Bunun yanı sıra, seferin Majorka, İskenderiye ve Konstantinopolis bölgelerinden hangisine yapılacağıyla ilgili maksatlı söylentiler çıkartılmıştı. Bununla da muhtemelen hedef şaşırtma amacı güdülmekteydi. ${ }^{39}$ Ancak İmparator Andronikos'un Haziran 1185'te, Normanların gelmesinden hemen önce loannes Bra-

32 La Continuation de l'Histoire des Croisades de Guillaume de Tyr, Collection des Mémoires Relatifs a l'Histoire de France, ed. ve modern Fransızca çev. Bernard le Trésorier, Paris, 1824, s. 146,148. 'Noveles aporta de la grant dolor qui estoit avenuë en la terre de promission. Il arriva en la terre le roi de Cesile et de Calabre et de Puille ... Il vint à lui et li conta le grant domage qui estoit avenu u roiaume de Jerusalem. Le roi en fu mult dolent et pensa qu'il estoit auques coupable de la perdition de la terre. Si vous dirai comment ... Si fist une estoire grant apareiller de naves et de galies. Il manda en la terre d'outre-mer et es autres contrées por chevaliers et serjans et lor donroit sous, selon ce que chascun seroit, et retint les pelerins qui en la Sainte Terre voloient passer, et tint ainsi deus ans les ports que nus ne pooit passer, si que des passages qui detint que de ceux qui vindrent d'outre-mer, fu la terre mult afeblie, et fu le roi de Jerusalem desconfit, qui poi de gent ot contre les Turcs; car quant Salahadin vint as cités et à chatiax, il ne trova qui li contredeist, ains li rendi l'on tot le roiaume, fors seulement Sur. Por ceste achaison dist le roi Guillaume qu'il fu durement coupable de la terre et de la perdition du roiaume...'

33 İbn Cübeyr, Rihletü'l-Kinânî, s. 252.

34 Eustathios (The Capture of Thessaloniki, s. 100-101, 106-109), Siphantos'un şehre ilk giren birliğin komutanı ve onun adamları tarafından tutuklanarak gemisinde rehinesi olduğunu kaydetmektedir.

35 Eustathios, The Capture of Thessaloniki, s. 62-63, 150-151.

36 V. ve XII. yüzyıllar arasında, özellikle Bizans İmparatorluğu tarafından kullanılan standart savaş gemisi. Tafsilâtlı bilgi için bkz.: John H. Pryor ve Elizabeth M. Jeffreys, The Age of Dromon: The Byzantine Navy ca 500-1204, Leiden-Boston, 2006.

37 İbn Cübeyr, Rihletü'l-Kinânî, s. 241, 253. Chalandon (Histoire de la Domination Normande, II, 386), İbn Cübeyr ve Eustathios'un öne sürdükleri gemi sayıları arasındaki farkı, donanmanın bir kısmının seferin ilk safhasında ele geçirilen Draç'ta ihtiyâtî olarak bırakılmasına bağlamaktadır. Fransız tarihçiye göre Selânik başpiskoposu, Sicilya'dan yelken açan donanmanın bütününden haberdar değildi.

38 Eustathios, The Capture of Thessaloniki, s. 62-63, 150-151.

39 İbn Cübeyr, Rihletü'l-Kinânî, s. 252-253. 
nas'ı, Epidamnos'a ${ }^{40}$ savunma önlemleri alması için yollamasından anlaşılmaktadır ki Bizans İmparatorluğu'nda Sicilya'daki hazırlıkların hedefinin kendileri olduğuyla ilgili pek kuşku bulunmuyordu..$^{41}$

Norman kara ordusunun komutası Kont Baudouin ve Richard d'Acerra'ya verilmişti. Donanma komutanlığı ise Lecce Kontu Tancred'e uygun görülmüştü. Bahsedilen komutanların önderliğindeki Norman askeri kuvvetleri, 1185 yılının haziran ayında denize açıldı. ${ }^{42} 24$ Haziran'da Dıraç'ta toplanan ordular, yeni vâli Branas'ın yetersiz kuvvetleri karşısında kolaylıkla üstün gelerek şehri ele geçirdiler. ${ }^{43}$ Branas, Andronikos'un insafına kalmaktansa Normanlara esir düşmeyi yeğleyerek Sicilya'ya götürüldü. ${ }^{44}$

Dıraç'ın hızlı düşüşü Selânik'te, çoğunlukla saldırganların lehine işleyen korku rüzgârları estirmeye başlamıştı bile. Dıraç'ta kalenin korunması için bir kısım birlik bırakııdı. Kara ordusu antik Via Egnetia yolu üzerinden Selânik'e yürürken donanma da şehre varmak için Mora Yarımadası çevresinden dolanmak üzere yola çıktı. Norman kara birlikleri 6 Ağustos sabahı Selânik'e vardılar ve kent surlarının dışında toplanmaya başladılar. Donanmanın şehre varması ise kara kuvvetlerinin yolculuğundan dokuz gün fazla sürdü ve Norman donanması 15 Ağustos'ta Selânik limanına giriş yaptı. ${ }^{45}$

Eustathios, kuşatma öncesinde arkadaş olduklarını belirttiği Selânik Vâlisi doux ${ }^{46}$ David Komnenos'un, kuşatma sırasında ortaya çıkan "anlamsız" davranışlarıyla birlikte "en ufak bir soyluluk belirtisi" göstermeyen, gaflet ve hatta hıyanet içinde olan, aptal ve korkak bir adam hâline geldiğinden bahsetmektedir. ${ }^{47}$ Normanların Selânik'i hedef alacağı ortaya çıktığında uzun süredir kullanım dışı olan Akropolis'deki48 sarnıç onarılmıştı. Ancak yapılan sıvanın kuruması için David'den birkaç gün daha sarnıca su verilmemesini isteyen Leo Mazidas adında birini dinlemeyen Vâli, kanalları açtırınca son yapılan tâdilâtın çökmesine sebep oldu ve sar-

40 'Ení́auvos, Dıraç'ın antik çağdaki ismidir. Bkz.: Timothy E. Gregory, “Dyrrachion”, The Oxford Dictionary of Byzantium, I, 668.

41 Khoniates, Niketas Khoniates'in Historia'sı, s. 107.

42 Annales Ceccanenses, ed. G. Pertz, Monumenta Germaniae Historica, Scriptores, XIX, Hannover, 1866, anno 1185, s. 287; Khoniates, Niketas Khoniates'in Historia'sı, s. 157-158.

43 Annales Cassinenses, anno 1185, 1190, s. 313; Annales Ceccanenses, anno 1185, s. 287; Annales Cavenses, ed. G. Pertz, Monumenta Germaniae Historica, Scriptores, III, Hannover, 1839, anno 1185, s. 193; Eustathios, The Capture of Thessaloniki, s. 64-65; Khoniates, Niketas Khoniates'in Historia'sı, s. 84, 107; La Continuation de l'Histoire des Croisades de Guillaume de Tyr, s. 150.

44 Eustathios, The Capture of Thessaloniki, s. 64-65; Khoniates, Niketas Khoniates'in Historia'sı, s. 107.

45 Eustathios, The Capture of Thessaloniki, s. 66-67.

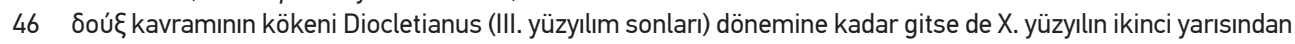
itibaren Selânik, Antakya, Edirne, Mezopotamya, İtalya gibi geniş yönetim bölgelerinin askerî kumandanlarını belirtmek için kullanılmaktaydı. Bkz.: Alexander P. Kazhdan, “Doux”, The Oxford Dictionary of Byzantium, I, 659.

47 Eustathios, The Capture of Thessaloniki, s. 16-19. David Komnenos için benzer suçlamalar, kaynağı Eustathios olduğundan dolayı Khoniates (Niketas Khoniates'in Historia'sı, s. 84-86) tarafından da yapılmaktadır.

48 Kelime anlamıyla 'tepedeki şehir' anlamına gelmektedir. Antikçağda yüksek ve doğal savunma sağlayan yerlere kurulan şehirler zamanla genişleyince akropolisler, şehir içinde kalan, istihkâm edilmiş hisar hâline geldiler. Akropolis'ler Ortaçağ'da iç kale işlevi görmeye devam edecekti. Bkz.: Ana Maria Cabanillas Whitaker, "Acropolis", Encyclopedia of the City, ed. Roger W. Caves, New York, 2005, s. 4-5. 
nıçtaki su birkaç günde boşaldı. Bununla birlikte şehirde bulunan mancınıkların, cephanenin ve surların yetersizliğinin ortaya çıkmasıyla ilgili olarak David hep aynı cevabı vermişti: “Ne yapabilirim ki?". Hatta bu tip şikâyetleri fazlaca dillendiren olursa onları infaza kadar giden ağır cezalarla tehdit ederek susturuyordu. Nitekim savunmayla ilgili görüşlerini açıkça belirtmesi elzem olan askerler bu şekilde sessiz kalmaya itilmişti. Bunlara bir de kuşatılan bir şehir için fevkalâde önem arz eden erzak depolanması işinin savsaklanması da eklenmişti. Savunma hazırlıklarını en son haddinde kötüleştiren tasarruf ise, zengin insanlara, mallarını ve sıradan insanları da yanında götürebilme izniyle birlikte kentten ayrılma izninin verilmiş olmasıydı. ${ }^{49}$ Zira tam donanımlı güçlü bir düşmanın pençesine düşmek üzere olan Selânik eli silâh tutan herkese ihtiyaç duyacaktı.

Selânik'i kuşatan Norman kara kuvvetleri şehrin batısındaki Via Egnetia'ya açılan Altın Kapı'nın önünde Acropolis'ten kıyıya kadar hilâl biçiminde pozisyon almasına karşın hantal kuşatma aletleri ve şehrin bu tarafındaki tahkimat kuvvetli olduğundan kuşatmanın batı kısmı pek etkin olamayacaktı. Norman donanması ise şehrin denize bakan kısımlarındaki surlara, yaz aylarında denizin çekilmesiyle sığlık meydana geldiği için yanaşamadı ve suların daha derin olduğu kentin doğu tarafından çıkarma yaparak kuşatmaya katıldı. 16 Ağustos'tan başlamak üzere, Asomatoi Kapısı'ndan kıyıya kadar yayılan doğu tarafındaki kuvvetler, geleneksel yöntemlerle hazırlık yaparak çoğunlukla küçük mancınıklar hazırladılar. Ancak mancınıklar arasında, biri “depremin kızı" diye tesmiye edilen iki büyük mancınık da vardı. Doğu tarafındaki Normanların bir kısmı çukurları doldurup surları yıkmak için tüneller kazarken diğer bir kısmı da onları korumak için surların üstündeki Bizans askerlerine yağmur gibi oklar yağdırıyordu. Aralarında Bulgar ve Estathios'un cesaretlerinden dolayı övgüyle bahsettiği Sırp birlikleri de olan Bizans kuvvetleri ise mukabil saldırıyla okçuları geriye püskürterek uzaklaştırıyorlardı. Benzer sahneler batı tarafındaki Norman kara ve deniz kuvvetleri için de gerçekleşmiş ve hatta bu taraftaki Sicilya birlikleri, Bizans okçularının menzilinin dışına çıkmak için gerilemek durumunda kalmışlardı. ${ }^{50}$

David Komnenos, kuşatma başlamadan hemen önce Normanlardan şehre yaklaşan birkaç askeri ele geçirerek ya da savuşturarak bunları Andronikos'a önemli başarılar olarak sunmuştu. Andronikos'a yazdığı mektuplarda şehrin gereken her şeye sahip olduğunu ve uzun bir kuşatmaya hazır olduğunu bildiriyordu. ${ }^{51}$ Ancak Andronikos buna pek güvenmemiş olacak ki,

49 Eustathios, The Capture of Thessaloniki, s. 75-79.

50 Eustathios, The Capture of Thessaloniki, s. 73-75, 94-95, 120-121.

51 Eustathios, The Capture of Thessaloniki, s. 68-71. Eustathios'un (The Capture of Thessaloniki, s. 72-73) eserinin birçok yerinde defâatle tekrar ettiği gibi David, Andronikos'un onu görevden alarak öldürmesinden çok korkuyordu. David korkusunda haksız değildi zira Vâli'nin aldığı önlemlerden dolayı onu tebrik eden imparator, bu tebriklerin gelecekte de devam etmesini umduğunu belirterek David'i alttan alta tehdit etmekle yetinmeyerek Konstantinopolis'te bulunan annesi ve erkek kardeşini de gözaltına aldırmıştı. 
oğlu loannes, khartularios $^{52}$ Theodoros Khumnos, Andronikos Palaiologos, parakoimomenos ${ }^{53}$ Nikephoros ve Aleksios Branas komutasında beş ayrı orduyu Selânik'in yardımına yolladı. Ancak oğlu loannes şehrin kurtarılmasının imkânsız olduğunu düşünerek zamanını Philippopolis (Bulgaristan'daki Filibe şehri) civarında av yaparak geçirmeyi tercih etti. ${ }^{54}$ Vâli'nin verdiği bilgiler sebebiyle ordu komutanlarına şehre yaklaşmamaları ve düşmanla çatışmaya girmemeleri emri verilmişti. Buna karşın Khumnos'un birlikleri şehrin doğusundaki Normanlara saldırdığı sırada Vâli David askerlerin zorlamasıyla içeriden bir huruç hareketine izin verdi. Ancak huruç yapan askerlerin ardından kale kapılarını hemen kapattırdı. Komutanlarının, onları kaderlerine terk ettiğini gören savunmacıların cesareti kırılmıştı. Eustathios'un şehir düştükten sonra Normanlardan duyduğuna göre eğer bu iki cepheli saldırı düzgün yapılmış olsaydı buradaki Norman kuvvetleri tamamen dağılacak, kıyıdaki gemileri de Bizanslıların eline geçecekti. ${ }^{55}$ Kuşatma sırasında şehrin batı tarafındaki Normanların pek etkin olamadığı hesaba katılacak olursa doğusundakilerin dağılması Selânik şehrini kurtarabilirdi. Bunlara ek olarak Vâli, Mora'dan ordusuyla Selânik'e yardım için gelen sebastos John Maurozomes'in tavsiyelerini de umursamadı. ${ }^{56}$

Mancınıkların yağdırdığı taşlar sebebiyle zayıflayan, şehrin doğu tarafındaki Chamaidrakon Kulesi'nin bulunduğu kısımdaki surlar, lağımcıların kazarak yerleştirdikleri payandaları tutuşturmasıyla 24 Ağustos'ta çöktü. Korsan Siphantos'un adamlarının mızraklarını surların üzerinde gören doux David, mahir askerleri yanına alarak Acropolis'e doğru dörtnala kaçmaya başladı. Bunu gören askerler onu ikaz etse de Vâli onlara kendisinin yaptığı gibi yapmalarını söyleyerek yoluna devam etti. Birkaç cesur savaşçı ve kendilerini bekleyen tehlikeye karşı direniş gösteren halk dışında birçok kişi David'in kervanına katıldı. Bu büyük kalabalık David'in peşinden Acropolis'in kapısına yığılınca doğal olarak izdiham gerçekleşti. Kadınlar, çocuklar ve daha niceleri hem üstlerinden geçen atlılar hem de yayalar tarafından çiğnendi. Üstüne üstlük bu kargaşa içinde Vâli'nin, altında birileri olmasına rağmen demir kapıyı indirtmesiyle olay çı̆̆ırından çıktı. Öyle ki, kapanan Acropolis kapısı önünde sıkışarak ölen kişilerin bedenleri, kapı önünde tepecik oluşturdular. Doğu surlarındaki savunmacılar hâlihazırda bedenen ve ruhen çökmüş durumda olduğundan komutanlarının en iyi askerleri yanına alarak firar etmesi, savunmaya öldürücü darbeyi indirmişti. Şehrin batısında ise Leon Loutalas isimli ce-

52 хартоu入ápıs, devlet dairelerindeki vergisel ve buna bağlı merkezi veyahut yerel arşivlerde görevli ikincil dereceli memurları belirtmek için kullanılan unvandır. Bu memurlar burada da bir örneğini gördüğümüz gibi imparatorlar tarafından askerî görevlere tayin edilebiliyorlardı. Bkz.: Alexander P. Kazhdan, "Chartoularios", The Oxford Dictionary of Byzantium, I, 416.

53 паракоıн́́ $\mu \varepsilon v о \varsigma$, kelime anlamıla imparatorun yanında uyuyan anlamına gelen, imparatorun yatak odası koruyucusu, saray hadımlarının en yüksek rütbesine verilen isimdir. IX. ve X. yüzyıllarda oldukça artan önemi, XII. yüzyıldan itibaren inişe geçmiştir. Bkz.: Alexander P. Kazhdan, "Parakoimomenos", The Oxford Dictionary of Byzantium, III, 1584.

54 Khoniates, Niketas Khoniates'in Historia'sı, s. 108-109. Khoniates'ten biraz farklı olarak Eustathios (The Capture of Thessaloniki, s. 72-73) yollanan birlik komutanlarını, doğu Megas Domestikos'u Gidos, Andronikos Palaiologos, Manuel Kamytzes, Khoumnos, parakoimomenos Nikephoros ve diğerleri şeklinde saymaktadır.

55 Eustathios, The Capture of Thessaloniki, s. 72-73, 86-87, 94-95.

56 Eustathios, The Capture of Thessaloniki, s. 88-89. 
sur bir asker, Normanlar kentin neredeyse her tarafına yayılana kadar savunmasını sürdürse de umut kalmadığını görerek Acropolis'e çekildi. Şehre doğudan giren Norman kuvvetlerini batıdaki birlikleri takip etmişti. Norman piyadelerinden sonra süvariler de şehre akın ettiler. Eustathios'un edindiği bilgiye göre, şehrin düştüğü günün seher vaktinde, içlerinden üç tanesi bir gün önce surlardan inerek Normanlara katılan batı tarafındaki surları korumakla görevli beş Alman atlı askeri, Normanlara kapıyı açmayı konuştuğu sırada Yunan bir balıkçı onları duymuş onlar da balıkçıyı öldürmeye teşebbüs etmişlerdi. Başpiskopos, Normanlara Draç'tan itibaren eşlik etmekte olan Theophanes Probatas isimli bir "hainden" de söz etmektedir. Bu kişi Almanlarla iletişim kurarak onları Norman saflarına çekmekte etkin olmuş olabilir. Buna ek olarak Bourgesioi isimli kulenin savunmasından sorumlu İliryalıların ${ }^{57}$ da saldırganlara kentin durumuyla ilgili bilgi aktardığını kaydetmektedir. ${ }^{58}$

15 Ağustos'ta donanmanın da gelişiyle birlikte başlayan kuşatma dokuz günün sonunda 24 Ağustos Cuma günü neticelendi ve İmparatorluğun ikinci büyük şehri Selânik Sicilya Krallığı'nın eline geçti. ${ }^{59}$

İki taraftan da şehre akın eden Normanlar, Ortaçağ'da kılıçla alınan kentlerde mutat olduğu üzere büyük bir vahşet yaptılar. Sokaklarda kaçışan hamile kadınlar, çocuklar ezildi, bebekler kaderlerine terk edildi, şehirdeki köpek ve kediler dahi öldürüldü veya ezildi, kimi kişiler kuyulara atlayarak kendini orada gizlemeye çalıştı, kimileri de düşmanın insafına kalmaktansa evlerinin çatılarından atlayarak intihar etti. Kiliselere kaçanlar da makûs talihten kurtulamayacaktı. Kutsal yerlerde küçük tuvaletlerini yapmaktan tutun da Eustathios'un Myrobletes ${ }^{60}$ olarak bahsettiği Selânikli Aziz Dimitrios'un türbesindeki kutsal emanetler olan azizin tacını ve ayağını talan etmeye kadar varan aşırılıklar yapmakla yetinmeyen yağmacılar, rahibe kızlara tecavüz edip din adamlarını katlettiler. Eustathios'un Sicilya Kralı́nın görevlisi olarak bahsettiği bir hadım emîr, yağmalanan bir kiliseye at üstünde topuzunu sallayarak girerek yağmacıları engellemişti. Buradan da anlaşılmaktadır ki doğu tarafından şehre ilk giren birlikler yukarıda bahsedildiği gibi servet peşindeki korsanlar ve maceracılardan oluştuğundan aşırılıklar bu boyutlara ulaşmıştı. Bununla birlikte yağma görece kısa sürdü, öğleden sonra Norman komutasının emriyle durduruldu. ${ }^{61}$

57 Eustathios'un Chounabitai ismiyle bahsettiği askerlerin Hun asıllı olma ihtimalleri vardır. Bkz.: Eustathios, The Capture of Thessaloniki, s. 92-93, 203.

58 Eustathios, The Capture of Thessaloniki, s. 8-11, 90-95, 100-105.

59 Annales Cassinenses, anno 1185, s. 313; Annales Ceccanenses, anno 1185, s. 287; Annales Cavenses, anno 1185, s. 193; Chronica Ignoti Monachi Cisterciensis S. Mariae de Ferraria, ed. A. Gaudenzi, Societa Napoletana di Storia Patria, Monumenti Storici, ser. I, Napoli 1888, anno 1184, s. 31; Eustathios, The Capture of Thessaloniki, s. 100-105; Khoniates, Niketas Khoniates'in Historia'sl, s. 86, 109; La Continuation de l'Histoire des Croisades de Guillaume de Tyr, s. 150.

60 Kelime anlamıyla "mürrüsafi (Tıpta ve eczacılıkta antik çağlardan beri kullanılan kokulu reçine sakızı) veren" anlamına gelir. Aslen Sirmium'lu olsa da Selânik'te yaşayıp orada ölerek şehrin azizi olarak kabul edilen "Büyük Şehit" lakabıyla da anılan Aziz Dimitrios için bkz.: Alexander P. Kazhdan, Nancy P. Sevcenko, "Demetrios of Thessalonike", The Oxford Dictionary of Byzantium, I, 605-606.

61 Eustathios, The Capture of Thessaloniki, s. 112-121. 
Ahâlinin ölülerini gömme ricasını reddeden Normanlar, insan cesetlerini aralarına karışmış hayvan ölüleriyle beraber yığarak yaktılar. Daha sonrasında şehirdeki evlere el koyarak yerleştiler. Dımdızlak dışarı atılan insanlardan şanslı olanlar sokakta buldukları paçavralarla üstlerini örttüler; kimileri de utanç içinde çırılçıplak dolaşmak durumunda kaldı. Yağma durdurulmuş olsa da hava karardığında disiplini sağlamak zor olduğundan kimi Norman askerleri kadınlara tecavüz etmek için güneşin batmasını bekleyecekti. ${ }^{62}$

Acropolis'i vakit kaybetmeksizin Normanlara teslim ederek, yukarıda Mora'dan ordusuyla yardım için geldiğinden bahsettiğimiz sebastos Maurozomes'le birlikte esir alınan doux David ise Sicilya'ya gönderildi. ${ }^{63}$

Eustathios, katliamda askerler de dahil 7.000 Bizanslının can verdiğini, Normanların kendi sayımına göre ise rakamın 5.000 olduğunu ifade etmektedir. Ayrıca başpiskopos, Normanların sadece sokaktaki cesetleri saydığını, evde ve kiliselerde havasızlıktan ölenleri hesap etmediklerini de belirtmektedir. Bununla birlikte başpiskoposun doğrudan Norman ordusunun komutanı Kont Baudouin'den duyduğuna göre ise Norman kaybı, kuşatma sırasındaki çatışmalar, hastalıklar ve diğer sebeplerle 3.000 civarındaydı. ${ }^{64}$

Ele geçirilen başpiskopos Eustathios ve beraberindekiler Siphantos'un adamları tarafından esir alınarak şehrin Hipodromuna götürüldüler. Orada diz üstünde bekletilen esirler, Siphantos'un gelip onları teftiş etmesinden sonra limana sevk edildiler. Başpiskopos at üstünde yaptığı bu yolculuk sırasında atın yerdeki cesetlerden dolayı zar zor ilerleyebildiğini zikretmektedir. Esirler Siphantos'un gemisine yerleştirildikten sonra başpiskopos ve beraberindekiler için 4.000 altın fidye belirlendi. Ertesi gün esirler Alexios Komnenos'a ${ }^{65}$ gösterildiler. ${ }^{66}$

Yağma durdurulmasına rağmen şehir halkı için eziyet bitmemişti. Eustathios, düşmanla iş birliği içinde şehir halkına eziyet yapmakla suçladığı Ermenilerin, pahalı fiyattan yiyecek satarak fırsatçılık yaptıklarını belirterek, eğer o yıın hasadı iyi olmasaydı herkesin açlıktan kırılacağını ifade etmektedir. Başpiskopos, pahalı yiyecek satma fırsatçılığı suçlamasını Yahudilere de yöneltmektedir. Bunun yanında komutanları Baudouin'in kazığa oturtmaya kadar varan cezalarına karşın Norman askerler, sürekli olarak taciz ettikleri halkı, özellikle geceleri fırsat bulduklarında evlerine girerek işkence edip mallarını nereye koyduklarını ortaya çıkararak gasp ediyorlar, kadınlarına tecavüz ediyorlar ve yaptıklarının kontun kulağına gitmemesi için ev ahâlisini ortadan kaldırıyorlardı. Hatta ahâliden Konstantinos Kekalesmenos adında zengin birinden bahseden başpiskopos, defalarca işkence yaptıkları adamdan her defasında

62 Eustathios, The Capture of Thessaloniki, s. 120-123.

63 Eustathios, The Capture of Thessaloniki, s. 10-15.

64 Eustathios, The Capture of Thessaloniki, s. 120-121, 148-151.

65 Burada bahsedilen Aleksios Komnenos yüksek ihtimalle yukarıda da bahsedilen Manuel'in sakisi olan kişidir. Zira sahte Aleksios'un sefere götürülmediği anlaşılıyor. Aynı isim ve soyadına sahip birden çok Aleksios Komnenos için Eustathios'un eserini tercüme eden Mellville Jones'un yorumlarına bakınız: Eustathios, The Capture of Thessaloniki, s. 234-236.

Eustathios, The Capture of Thessaloniki, s. 106-109. 
biraz daha fazla para koparan Norman askerlerinin, adamın onları Baudouin'e şikayetle tehdit etme gafletine düşmesi üzerine kafasını kesip gömdüklerini, vücudunu da sokağa attıklarını kaydetmektedir. Ahâliden gülen ya da somurtan birisine rastladıklarında o kişiyi tartaklıyorlar, uzun saçı ve sakalı olanları o sırada ellerinde bulunan herhangi bir kesici aletle (hatta kılıçlarıyla) tıraş ediyorlardı. Bunları yaparken şehri kılıçla aldıklarını belirtip buna hakları olduğunu, bununla birlikte Kral William'ın kentteki herkesi öldürmeleri için kendilerine izin vermesini beklediklerini söyleyerek tehditler savuruyorlardı. Ayrıca açlıktan ve güvensizlikten kaçınmak için Norman askerleriyle birlikte olan evli kadınlar, bakire kızlarını satan babalar da vardı. Başpiskopos durumlarını utanç verici olarak nitelediği bu kadınlara öğüt verdiğinde kadınlar onun kulağına "Köpeğe bağırsağın tadına bakması için izin vermemelisin" diye fısıldıyorlardı. Başpiskoposu, Baudouin'e sürekli şikâyette bulunmak zorunda bırakan, Normanların en rahatsız edici hareketleri ise kiliselerdeki ayinleri gürültü yaparak bozmalarıydı. Özellikle dine karşı yapılan bu aşağılamaları engellemeye çalışan Baudouin altın, gümüş, kitap ve değerli eşyalar bağışlayarak Ortodoksları teskin etmeye çalışıyordu. ${ }^{67}$

\section{Kuşatma Sonrası}

Selânik'in işgâlinden sonra vakit kaybetmeyen Normanlar, ordularını üçe böldüler. Donanma Selânik'te kalırken, kalan iki kara ordusundan biri araziyi yağmalayarak ilerlediği yolda Serrai'ye, ${ }^{68}$ diğeri de Via Egnetia üzerinde mukavemetle karşılaşmaksızın ilerleyerek Mosinopolis ${ }^{69}$ önlerine varıp kamp kurarak çevreyi itaat altına aldı. Ancak Mosinopolis'e kadar ilerleyen ordunun bir kısmı Struma Nehri'nin kıyıya döküldüğü yere yakın olan Amfipolis'i tahrip etmekle oyalanırken Mosinopolis'teki kısmı da çevreye dağılmıştı. ${ }^{70}$

Selânik'in düşmesinden önce Konstantinopolis surlarının sağlamlaştırılmasını emreden İmparator Andronikos, sura bitişik evleri yıktırarak şehrin kara tarafından savunmasını güçlendirmekle yetinmeyip takribî 100 gemiyi de Haliç'te hazır bekletiyordu. Selânik'in düştüğü haberini alınca doux David'in yukarıda bahsedilen akrabalarını hapse attırdı. İmparator, Sicilyalıların Mosinopolis'e kadar vardıkları haberini aldığında tehditler savursa da anlaşılmaz bir şekilde âtıl kaldı. İmparatorluğun başkentine, Konstantinopolis'e ilerlemekte olan düşmana karşı etkisiz kalan Andronikos, Norman tehdidinin sebebini siyasî düşmanları üzerine yüklemeye kalktı. Andronikos'un hâlihazırda dayanılmaz bir halde olan tedhiş rejimi, hapiste ve sürgündeki muhaliflerin akrabaları ve yakınlarıyla birlikte idamını emreden kararnameyi infaz listesiyle birlikte ilan etmesiyle dehşet verici bir noktaya geldi. İmparatorla herhangi bir sorunu bulunmayan Isaakios Angelos, Sulu Manastır ${ }^{71}$ yakınındaki evine kendisini tutuklamaya

67 Eustathios, The Capture of Thessaloniki, s. 125-141.

68 Selânik'in kuzeydoğusunda bulunan günümüzdeki adıyla Serez.

69 Gümülcine'nin beş km. batısında yer alır.

70 Khoniates, Niketas Khoniates'in Historia'sı, s. 107, 109-1 10, 156. Üç yerleşim yeri (Serez-Amfipolis-Mosinopolis) arasında dağılan iki Norman ordusu, bu kentler arasındaki mesafenin yaklaşık 200 km. olduğu göz önüne alınırsa darmadağınık bir hâldeydi.

71 Günümüzde Samatya'da bulunan Surp Kevork Ermeni Kilisesi. 
gelen kişiyi atına atlayarak öldürdü ve yoluna Konstantinopolis sokakları ve caddeleri boyunca at üstünde devam ederek Ayasofya'ya kadar yaptığı eylemi bütün halka ilân etti. Bu olay Andronikos'a karşı, korkunun tuttuğu nefret barajını yıktı ve İmparator Andronikos 11 Eylül 1185 günü Konstantinopolis'ten kaçmak zorunda kaldı. İsyanı ateşleyen II. Isaakios Angelos (1185-1195, 1203-1204) halk tarafından hükümdar ilân edildi. ${ }^{72}$

Andronikos'tan kurtulmanın verdiği moralle Bizanslılar, kurtarıcıları Isaakios'un Normanları topraklarından atmak için giriştiği çabaya destek olarak bütün eyaletlerden orduya akın ettiler. Bunlar arasında Andronikos tarafından ordudan uzaklaştırılmış tecrübeli askerler de bulunuyordu. Branas'ın komutasında bir araya gelen askerlere altın da dağıtıldı. Bu sırada Isaakios, Norman komutanı Baudouin'e imparatorluk topraklarını derhal terk etmesi için elçiler yolladı. Baudouin buna cevabında, alay ettiği imparatorun tahttan çekilmesini ve Kral William'ın önünde diz çökerek canının bağışlanması için yalvarmasını tavsiye etti. ${ }^{73}$

Norman ordusu, Bizans tarafından gelecek bir tehditten korkmaksızın Selânik'ten Gümülcine'ye kadar dağılmış bir şekilde küçük gruplara ayrılmıştı. Branas, Rodop Dağları'na çekilmiş Norman ordusunu takip eden Bizans kuvvetlerini de yanına katarak Batı Trakya'ya doğru ilerledi. Norman öncü kuvvetlerini dağıtan Bizanslı komutan onları Mosinopolis'e kadar sürdü. Kentin kapısını yakarak içeri giren Bizanslılar, Normanlardan kimi buldularsa katlettiler. Süratle Kavala üzerinden Amfipolis'e yaklaşarak toplanmak için zaman kazanmaya çalışan Normanları savaşa zorladılar. Demetritzes' $\mathrm{e}^{74}$ kadar çekilen Normanlar, Branas'a elçi yollayarak barış teklifinde bulundular. Branas, düşmanın zaman kazanmaya çalıştığını düşünerek barış görüşmeleri sürdüğü sırada, 7 Kasım 1185 gününün öğleden sonrasında aniden saldırıya geçti. Normanlar bir süre direndilerse de sonunda dağılarak kaçmaya başladılar. Struma Nehri'ni aşamayanlar öldürüldü ya da esir alındılar. Norman ordusunun iki komutanı, Kont Baudouin ve Richard d'Acerra da esirler arasındaydı. Savaşa yetişemeyen Serez çevresindeki Norman askerleri ve savaştan sağ kurtulanlar var güçleriyle Selânik'e doğru kaçtılar. Şehirden de süratle kaçmaya çalışanlar içinde limandaki gemilerde yer bulamayan Normanlar, şehir Normanların eline düştüğünde yakınları katliama uğrayan Alanların intikam hırsıyla yüzleşmek zorunda kalacaklardı. Bizans ordusunun öncü birliği olduğu düşünülen Alan savaşçıları, esir aldıkları askerleri “Benim kardeşim nerede, Benim babam (papaz) nerede?” diye sorduktan sonra katlediyorlardı. Sokakları ve kilise avlularını Norman cesetleriyle doldurdular. Bu sırada saki Aleksios Komnenos da ele geçirilerek gözlerine mil çekildi. Geriye kalan Norman askerleri kendilerini zor bela Draç'a attılar. Draç, William'ın inadıyla bir süre daha Normanların elinde kalsa da nihayetinde bir yıl sonra tahliye edilecekti. ${ }^{75}$

72 Khoniates, Niketas Khoniates'in Historia'sı, s. 111-112, 130-133, 136-143.

73 Khoniates, Niketas Khoniates'in Historia'sı, s. 154-155, 163-164.

74 Serez'in yaklaşık 20 km. güneybatısında yer alan, günümüzdeki adıyla Dimitritsi Kasabası.

75 Khoniates, Niketas Khoniates'in Historia'sı, s. 155-160. 
Norman kara güçleri Selânik'ten Trakya'ya doğru yol almaya başladığında şehirdeki Norman donanması da Lecceli Tancred'in amiralliğinde, 200 gemilik bir filoyla Konstantinopolis'e doğru yelken açmıştı. Prens Adaları'nda ${ }^{76}$ demirleyen donanma kara ordusunun gelmesini bekliyordu. Tancred, Astakenos Körfezi'ne ${ }^{77}$ asker çıkarmaya çalıştıysa da Bizanslılar buna izin vermedi. Isaakios, kıyılara her yanaştığında yerel halk ve askerler tarafından sürekli saldırıya uğrayan Normanlara karşı, o sırada Kiones'te ${ }^{78}$ demirlemiş olan 100 kadırgalık imparatorluk filosunu harekete geçirmeyi gerek görmedi. Zira düşmanlarla çevrili bir iç denizde Normanlar, karadan da destek gelmeyeceği hesaba katılırsa eninde sonunda Marmara Denizi'ni terk etmek zorunda kalacaklardı. 17 günlük beklemenin sonunda kara ordusundan umudunu kesen Norman filosu, Prens Adaları'yla birlikte el koydukları Kalonymos Adası'nı ${ }^{79}$ da tahliye ederek Çanakkale Boğazı'na doğru yelken açtı. Dönüş yolunda Hellespont ${ }^{80}$ bölgesindeki kıyıları ateşe verdiler. Khoniates'e göre donanmanın ancak yarısı Sicilya'ya dönmeyi başarabilmişti. ${ }^{81}$

Khoniates'e göre Bizans karşı saldırısında 10.000 Norman ölürken, 4.000'i de çok kötü koşullar içinde olacakları esarete düşmüşlerdi. Daha sonrasında esirlerin durumunu öğrenen Kral William, Isaakios'a mektup yazarak, onu vicdansızlıkla suçladı. İmparator, kralın mektubunu umursamayarak esarette her gün birkaçı ölen Norman askerlerinin cesetlerinin zindandan çıkarılarak derin çukurlara atılmasına göz yumdu. Daha sonrasında Isaakios, esirler arasındaki Norman komutanları Kont Baudouin ve Richard d'Acerra'nın huzuruna getirilmesini emretti. İmparator, Baudouin'le gerçekleştirdiği yazışmayı ona hatırlatarak iki komutanın da idamını emretti. Ancak Norman komutan onu pohpohlayarak gönlünü aldı ve iki komutan da canını kurtarmaya muvaffak oldu. ${ }^{82}$

Sicilya Normanları ve Bizans İmparatorluğu arasındaki çatışma bir süre daha devam edecekti. Barış anlaşmasının ne zaman yapıldığı bilinmese de II. William'ın, Hittîn Savaşı'ndan (Temmuz 1187) sonra Levant'tan tamamen sürülme riskiyle karşı karşıya kalan Haçlılara yardım edebilmek adına, 1187 ilkbaharında Kıbrıs'ta tekrardan çatışmaya girdiği Isaakios ile barış istemiş olması muhtemeldir. ${ }^{83}$ Zira Hittîn Savaşı bu çatışmadan birkaç ay sonra gerçekleşecekti. 1189'da esir komutanlardan Richard d'Acerra'nın İtalya'da bulunduğunu görmemiz bu ihtimali daha da kuvvetlendirmektedir. ${ }^{84}$

76 İstanbul'un Anadolu yakasının Marmara Denizi'ne bakan kısmının hemen karşısında, İstanbullular tarafından Adalar diye adlandırılan takımadadır.

77 İzmit Körfezi.

78 Kiones (Diplokionion) günümüzdeki Beşiktaş kıyılarıdır.

79 İmralı Adası.

80 Çanakkale Boğazı'nın eski adı.

81 Khoniates, Niketas Khoniates'in Historia'sı, s. 155, 161-162.

82 Khoniates, Niketas Khoniates'in Historia'sl, s. 162-165.

83 Sicilyalı ünlü amiral, Brindisi'li Margaritus'un Kıbrıs seferiyle ilgili bkz.: Chalandon, Histoire de la Domination Normande, II, 415; Stanton, Norman Naval Operations, s. 156; Murat Öztürk, "Sicilya Normanlarının Doğu Akdeniz'deki Bahrî Faaliyetleri 549-584 (1154-1189)", FSM IIlmî Araştırmalar İnsan ve Toplum Bilimleri Dergisi, 14 (2019), s. 214-215.

84 Annales Ceccanenses, s. 287-288. 


\section{Sonuç}

Kral William Selânik'e saldırarak, 1174, 1176-1177 ve 1177-78'de İskenderiye ${ }^{85}$ ve 1181 'de Balear Adaları'na ${ }^{86}$ yaptığına benzer, çok maliyetli ancak yine başarısızlıkla sonuçlanan bir girişimde bulunmuştu. Bizans'a yaptığı saldırı imparatorluğu müşkül bir zamanında yakalasa da bu, Kral'ın bahsedilen diğer seferlerinde de görülebileceği gibi siyasal hedefleri net bir şekilde belirlenmemiş bir harekâttı. Bu belirsizliğin en açık göstergelerinden biri, Selânik'in alınmasından sonra Norman ordusunun, Konstantinopolis karışıklık içinde olmasına rağmen Batı Trakya'da zaman kaybetmesidir. Krallığın sadece maddi değil manevi enerjisini de tüketmişe benzeyen girişim, William'ın Alman Prensi'ne tahtın yegâne vârisi olan halasını gelin göndermek gibi ölümcül bir hatayla üst üste gelince, Akdeniz'in başat gücü konumundaki Hauteville hânedanı kısa sürede inkıraza sürüklenecek, Sicilya Kralığı, Alman imparatorlarının unvanlarından biri hâline gelecekti.

Bizans tarafına bakıldığında ise, imparatorluğun Manuel'in ölümünden beri girdiği girdapta Selânik ilk sahneyi oluşturacaktı. Zira içten içe çürümekte olan imparatorlukta Komnenos hânedanının devrilmesinin yarattığı etki, Konstantinopolis'in Haçlılar tarafından zaptına dek sürecek ve Bizans İmparatorluğu birbirleriyle rekabet halinde üç ayrı devlete bölünecekti.

Sefer öncesinde, sırasında ve sonrasında Bizans'ın ve Normanların birbirlerine karşı yaptıkları aşırılıklar, Bizans-Latin karşıtığını oldukça ileri boyutlara taşıyacak, Selânik saldırısından önce de asırlardır birbirlerine düşmanlık besleyen bu iki Hristiyan uygarlığı, daha sonrasında birçok Avrupa devletinin de dahil olacağı çatışmalara girişecekti.

\footnotetext{
Hakem Değerlendirmesi: Dış bağımsız.

Çıkar Çatışması: Yazar çıkar çatışması bildirmemiştir.

Finansal Destek: Yazar bu çalışma için finansal destek almadığını beyan etmiş̧tir.
}

Peer-review: Externally peer-reviewed.

Conflict of Interest: The author has no conflict of interest to declare.

Grant Support: The author declared that this study has received no financial support.

\section{Bibliyografya}

Ahrweiler, Hélène, Byzance et la Mer, la marine de guerre: la Politique et les Institutions Maritimes de Byzance aux VIle-XVe siecles, Paris, 1966.

Altan, Ebru, Antakya Haçlı Prinkepsliği Tarihi, Kuruluş Devri (1098-1112), Ankara: TTK, 2018.

Altan, Ebru, Ikinci Haçlı Seferi (1147-1148), Ankara: TTK, 2003.

85 Bu iki sefer için bkz.: Chalandon, Histoire de la Domination Normande, II, 395-397; Stanton, Norman Naval Operations, s. 146-148; Öztürk, “Sicilya Normanlarının Doğu Akdeniz'deki Bahrî Faaliyetleri”, s. 207-212.

86 Chalandon, Histoire de la Domination Normande, II, 398; Stanton, Norman Naval Operations, s. 149-150. 
Annales Cassinenses, a. 1000-1212, ed. G. Pertz, Monumenta Germaniae Historica, Scriptores, XIX, Hannover, 1866, anno 1185, 1190, s. 313-314.

Annales Ceccanenses, ed. G. Pertz, Monumenta Germaniae Historica, Scriptores, XIX, Hannover, 1866, anno 1185, s. 287.

Annales Cavenses, ed. G. Pertz, Monumenta Germaniae Historica, Scriptores, III, Hannover, 1839, anno 1185, s. 193.

Aubé, Pierre, Les empires normands d'Orient: Xle-XIIle siècle, Paris, 1983.

Brand, Charles M., Byzantium Confronts the West 1180-1204, Cambridge, Massachusetts: Harvard University Press, 1968.

Chalandon, Ferdinand, Histoire de la Domination Normande en Italie et en Sicile, I-II, Paris, 1907.

Chronica Ignoti Monachi Cisterciensis S. Mariae de Ferraria, ed. A. Gaudenzi, Societa Napoletana di Storia Patria, Monumenti Storici, ser. I, Napoli 1888, anno 1184, s. 31.

Eustathios of Thessaloniki, The Capture of Thessaloniki, İngilizce çev. John R. Melville Jones, Canberra, 1988.

Gregory, Timothy E., “Dyrrachion”, The Oxford Dictionary of Byzantium, I, 668.

İbn Cübeyr, Riḥletü'l-Kinânî, çev. İsmail Güler, Endülüsten Kutsal Topraklara, İstanbul, 2008.

Kazhdan, Alexander P., "Doux”, The Oxford Dictionary of Byzantium, I, 659.

Kazhdan, Alexander P., "Parakoimomenos”, The Oxford Dictionary of Byzantium, III, 1584.

Kazhdan, Alexander P.-Nancy P. Sevcenko, "Demetrios of Thessalonike", The Oxford Dictionary of Byzantium, I, 605-606.

Khoniates, Niketas, Niketas Khoniates'in Historia'sı (1180-1195): Komnenos Hânedanı'nın Sonu ve II. Isaakios Angelos Devri, çev. Işın Demirkent, İstanbul, 2006.

Khoniates, Niketas, Historia (loannes ve Manuel Komnenos Devirleri), çev. Fikret Işıltan, Ankara, 1995. Kinnamos, loannes, loannes Kinnamos Historia'sı (1118-1176), çev. Işın Demirkent, Ankara: TTK, 2001.

La Continuation de l'Histoire des Croisades de Guillaume de Tyr, Collection des Mémoires Relatifs a l'Histoire de France, ed. ve modern Fransızca çev. Bernard le Trésorier, Paris, 1824.

la Lumia, Isidoro, Storie Siciliane, I, Palermo, 1881.

Loud, G. A., The Age of Guiscard: Southern Italy and the Norman Conquest, New York, 2013.

Murray, Alan V., “Outremer", The Crusades: An Encyclopedia (Santa Barbara, 2006), III, 911-912.

Norwich, John Julius, The Kingdom in the Sun 1130-1194, New York, 1970.

Ostrogorsky, Georg, Bizans Devleti Tarihi, Ankara: TTK, 2015.

Öztürk, Murat, “Sicilya Normanlarının Doğu Akdeniz'deki Bahrî Faaliyetleri 549-584 (1 154-1189)", FSM IIlmî Araştırmalar Insan ve Toplum Bilimleri Dergisi, 14 (2019), s. 195-228.

Pryor, John H. ve Elizabeth M. Jeffreys, The Age of Dromon: The Byzantine Navy ca 500-1204, LeidenBoston, 2006.

Raybaud, L. P. (Gouvernement), “Protosebastos”, The Oxford Dictionary of Byzantium, III, 1741.

Rogers, Randall, Latin Siege Warfare in the Twelfth Century, Oxford, 1992.

Salernolu Romuald, Romualdi Salernitani Chronicon [A. m. 130 - A. C. 1178], ed. C. Garufi, Rerum Italicarum Scriptores, nuova editione, vol. VII, Città di Castello, 1935.

Stanton, Charles D., Norman Naval Operations in the Mediterranean, Woodbridge, 2016.

Stephenson, Paul, Byzantium's Balkan Frontier a Political Study of the Northern Balkans, 900-1204, Cambridge, 2000. 
Tafrali, Oreste, Thessalonique des origines au XIVe siècle, Paris, 1919.

Theotokis, Georgios, The Norman Campaigns in the Balkans 1081-1108, Woodbridge, 2014.

Treadgold, Warren, The Middle Byzantine Historians, Basingstoke, 2013.

Whitaker, Maria Cabanillas, “Acropolis”, Encyclopedia of the City, ed. Roger W. Caves, New York 2005, s. 4-5. 